\title{
Traditional uses of Iraqi medicinal plants (part 2)
}

\author{
Ali Esmail Al-Snafi * \\ Department of Pharmacology, College of Medicine, University of Thi qar, Iraq.
}

International Journal of Biological and Pharmaceutical Sciences Archive, 2021, 02(01), 022-041

Publication history: Received on 01 June 2021; revised on 04 July 2021; accepted on 08 July 2021

Article DOI: https://doi.org/10.53771/ijbpsa.2021.2.1.0057

\begin{abstract}
As a result of accumulated experience from the past generations, today, all the world's cultures have an extensive knowledge of herbal medicine. In recent years, ethno medicinal studies has received much attention as this brings to light the numerous little known and unknown medicinal virtues especially of plant origin which needs evaluation on modern scientific lines such as phytochemical analysis, pharmacological screening and clinical trials. This review was designed to highlight the traditional uses of medicinal plants.
\end{abstract}

Keywords: Traditional Uses; Plants; Herbs; Antioxidant

\section{Introduction}

Plants are a valuable source of a wide range of secondary metabolites, which are used as pharmaceuticals, agrochemicals, flavours, fragrances, colours, biopesticides and food additives. Recent reviews revealed that the medicinal plants possessed central nervous [1], cardiovascular [2], antioxidant [3], reproductive [4-5], gastro-intestinal [6-7], respiratory [8], antidiabetic [9], antimicrobial [10-12], antiparasitic [13], anticancer [14], dermatological [15], anti-inflammatory, antipyretic and analgesic [16-17], immunological [18], hepato and reno-protective [19-20] and many other pharmacological effects. In our previous paper [21], we discussed the traditional uses of Iraqi medicinal plants. This review - which represented the second part-Web Science, Pub Med, Scopus and Science Direct, were searched for the traditional uses of plants grown in Iraq.

\section{Traditional uses of medicinal plants}

\subsection{Lagerstroemia indica}

The plant had a long history of folkloric medical uses included: blood pressure control, urinary dysfunctions, to control the cholesterol levels, as analgesic, in treatment of diarrhea, to facilitate bowel movement, and in the treatment of diabetes. Seeds were used as narcotic. Bark was used as stimulant and febrifuge. Leaves and flowers were used as purgative. The root was used as an astringent, detoxicant and used as diuretic and gargle [22-24].

\subsection{Lagerstroemia speciosa}

The roots were used as astringent, stimulant and febrifuge, it was also used for stomach problems. Tea of the leaves was used in the treatment of diabetes mellitus and for weight loss. The leaves, flowers and barks were used as purgative. Leaf decoction or infusion was used for bladder and kidney inflammation, dysuria and other urinary dysfunctions, for cholesterol deduction, hypertension and diabetes. Poultice of the leaves was used as remedy for malaria, headache and

\footnotetext{
*Corresponding author: Ali Esmail Al-Snafi

Department of Pharmacology, College of Medicine, University of Thi qar,Iraq..

Copyright (C 2021 Author(s) retain the copyright of this article. This article is published under the terms of the Creative Commons Attribution Liscense 4.0.
} 
cracked heeling by application over the lesions. Decoction of the bark was used for gastrointestinal tract disturbance, stomachache, haematuria and depression. The seeds were used as narcotic [25].

\subsection{Lallemantia iberica}

Lallemantia iberica seeds were traditionally used as reconstitute, stimulant, diuretic, expectorant, for the treatment of common cold, coughing, stomach and abdominal pain [26-27]. Its seed contained mucilage which used in the treatment of nervous, hepatic and renal diseases and as general tonic [28]. Oil was used for lighting, as a varnish, in paints and as a lubricant. The oil may also be used for oil-foods and as a tanning agent. It is considered as a linseed substitute in a number of applications including: wood preservative, ingredient of oil-based paints, furniture polishes, printing inks and soap making. It is also used in the manufacture of linoleum [29-31].

\subsection{Lallemantia royleana}

Seeds were used as cooling, diuretic, sedative; as a soothing agent during urinary troubles, fever, common cold, intestinal troubles. It was also used as cephalic astringent, cardiac tonic, carminative and for cough. A poultice of seeds was applied to abscesses, boils and inflammations. In Ivory Coast, Burkina Faso, Gabon and Tanganyika, different parts of the plant were used for the treatment of intercostals pain, rheumatic pain and fever. The leaf and root decoctions were used to treat pneumonia [32-33]. Muslim used its seeds in drinks as flavoring, cooling, soothing and sedative. Seeds also applied as one composition of herbal mixtures for anxiety and depression disorders. Seeds mucilage also applied as a liniment for skin complications. The seeds were used in Iranian traditional medicine as diuretic, tonic, aphrodisiac, and antitussive and for the treatment of various nervous, hepatic, and renal disorders [34-36].

\subsection{Lantana camara}

Traditionally, the plant was used as diaphoretic, carminative, antispasmodic, tonic, antiemetic, to treat respiratory infections and disorders (cough, cold, asthma, and bronchitis), in the treatment of tetanus, epilepsy, dysentery and gastropathy. Powdered leaves were used for cuts, wounds, ulcers, and swellings. An infusion of the leaves was used for bilious fever, eczema, and eruptions. The fruits were used in fistula, pustules, tumors, and rheumatism. The root was used in malarial, rheumatism, skin rashes, dermatitis, eczema, mycotic infections and respiratory tract infections including influenza and tuberculosis. A decoction of fresh roots was used as gargle for odontalgia [37-40].

\subsection{Lathyrus sativus}

The seeds oil was used medicinally as a powerful cathartic. It was also used in Bangladesh to cure scabies, eczema and allergy. Immature pods were cooked and eaten as a vegetable, or boiled, salted and consumed as a snack. Young vegetative parts were cooked as a green vegetable; they were also dried for off-season use as a vegetable in Asia. In India, the whole seeds were sometimes boiled, but were most often processed into dhal. The flour, made by grinding either the whole or split seeds, was sold as (besan). Grass pea was sometimes used to adulterate more expensive pulses, such as chickpea or pigeon pea. In Bangladesh (roti) made out of grass pea flour was a staple for landless laborers. In Ethiopia and Eritrea grass pea seeds were mainly consumed in the form of sauces (wot), shirowot (sauce made of flour) and kikwot (sauce made of hulled split seeds) and were eaten together with injera (a pancake-like unleavened bread). Boiled grass pea seeds (nifro) were also consumed in most areas, whereas kitta (an unleavened bread) made from grass pea seeds was consumed mainly during times of acute food shortage. Young grass pea plants were used as fodder for cattle or for grazing in many countries. As fodder, the plants can be eaten green or as hay [41-45].

\subsection{Lawsonia inermis}

Leaves of Lawsonia inermis provide an important cosmetic dye. Henna leaves were extensively used for centuries in the Middle East, the Far East and Northern Africa as dye for nails, hands, hair and textile. Henna was also used in treating skin problems, headache, jaundice, amebiasis and enlargement of the spleen [46-47].

\subsection{Lemna minor}

The whole plant was used as antipruritic, antiscorbutic, astringent, depurative, diuretic, febrifuge and soporific. It was also used in the treatment of colds, measles, oedema and difficulty in urination. In addition, it was used in the treatment of vitiligo, podagra, and upper respiratory tract inflammation. Duckweed formulations were used in the treatment of rheumatism, liver diseases, and thyroid diseases. As external application, duckweed formulations were used in the treatment of abscesses, chronic wounds, and furuncles [48-49]. It was used internally, in combination with other medicinal herbs, to treat inflammation of the upper respiratory tract, and as a anti-inflammatory and blood purifying remedy for chronic rheumatic ailments such as rheumatoid arthritis and osteoarthritis. In China, the herb was used 
internally for body temperature regulation (reduce high fever) and swellings (edema). Externally it was applied as a remedy for various skin ailments, such as rash, eczema, measles, and insect bites [50-51].

\subsection{Leontice leontopetalum}

The tuber was used in the treatment of epilepsy and leprosy. It was also used as snakebite opium poisoning antidotes. A soap was obtained from the plant, it was used in removing stains from cloth $(5,7)$. The plant roots were used in the treatment of rheumatism, joint pain and inflammation in Iran [52]. It was recommended to prevent benign prostatic enlargement, preventing breast, lymphoblastic, uterine and prostate cancers and for irregular menstrual periods, prevent menstrual cycle and postmenstrual syndrome, migraine, and development of myoma [53]. Tuber of Leontice leontopetalum subsp. leontopetalum was used for haemorrhoids in Turkey, the tubers were pulled out of the ground and sliced, then swallowed as a pill twice a day [54].

\subsection{Lepidium sativum}

The seeds of Lepidium sativum were used as aperient, diuretic, tonic, demulcent, carminative, galatogogue, emmenagogue, to cure throat diseases, uterine tumour, nasal polyps and breast cancer. Seeds were supplemented in the diet of lactating women to increase the milk secretion during post-natal period. Seeds also applied as a poultice to pains, hurts, sprains, in the treatment of bacterial and fungal infections [55-58]. The seeds were also used for treatment of fracture healing in Saudi traditional medicine [59]. In Unani system of medicine, seeds and leaves were used as diuretics, aperient and aphrodisiac and were recommended in inflammation, bronchitis, rheumatism and muscular pain (12). In Turkish folk medicine Lepidium sativum was used as to enhance digestion, as carminative and appetizer [60]. The plant was eaten and seed oil was used in treating dysentery, diarrhea and migraine [61]. The mucilage in the outer seed was used as substitute for tragacanth and gum Arabic [62-63].

\subsection{Linaria cymbalaria (Syn: Cymbalaria muralis)}

The herb was eaten as a salad in southern Europe, being acrid and pungent like cress. It was used as antiscorbutic, diuretic and tonic. Externally, it was used as a poultice on fresh wounds to stop the bleeding and as vulnerary. In India, it was used for the treatment of diabetes. The plant was also used in the treatment of haemorrhoids, scurvy, as a poultice to heal wounds and the infusion of the flowers was used as a diuretic in the Canary Islands. The flowers can be made into a non-permanent yellow dye [64-67].

\subsection{Linum usitatissimum}

Flax was being used as a food source dating back to ancient Greeks and Egyptians. It was also used as a food in Asia and Africa. In addition, it was used to supplement the diets of both ruminants and non-ruminants. Flax fiber was used by the prehistoric Lake Dwellers of Switzerland for the production of linen > 5000 years BP. However, the art of weaving flax fiber to linen may have originated in Egypt because winding-clothes for the bodies of the Pharaohs of Egypt were composed of flax fiber. It was then introduced in India, before the use of cotton [68-69]. The plant was used in the treatment of fever. Seeds were used as a laxative, soothing, pain relieving, for inflammation of digestive and urinary tracts, and as antidiarrhoeic. Seeds also used in preparation of cataplasms for their emollient prosperities against boils and inflammations [70-71].

In Pakistan, linseed was used on all kinds of local inflammations, sores and ulcers. Mucilage of linseed has been applied to the affected areas to resolve or to suppurate hard swellings; to relieve pain and to subside the affected inflamed areas. It was also used as paste or ointment in pleurisy, pneumonia, inflammation in bronchioles, peritonitis as well as inflammatory swellings in rheumatism. In China, it was used for constipation, dryness and itching of the skin, withering and loss of hair [72].

\subsection{Lippia nodiflora (Phyla nodiflora)}

The aerial parts were used as anodyne, antibacterial, emmenogogue, parasiticide, refrigerant, febrifuge, cooling, in treatment of wounds, asthma, thirst and loss of consciousness [73-74]. The plant made into a poultice to be used as maturant for boils. The infusion of leaves and tender stalks was used in children for indigestion and to women after delivery. Chutney made from the plant leaves and fruits were eaten to relive the irritation of internal piles [75]. In Ayurveda and Unani system of medicine, the plant was used as aphrodisiac, diuretic, and for the treatment of heart diseases, ulcers, bronchitis, fevers, cold, knee joint pain and in lithiasis [76-78]. 


\subsection{Lithospermum officinale}

In former times, Lithospermum officinale was used as a remedy in diseases of the urogenital tract and as a spasmolytic drug. Lithospermum ruderale was used as an antidiarrhoeal drug by Indians in North America; a few tribes in Nevada used cold water extracts of the root as an oral contraceptive. In India, leaves were used as sedative. Seeds were used as diuretic and lithotriptic. A decoction of roots and twigs was given in the form of syrup in eruptive diseases, such as smallpox and measles [79]. However, the aerial parts and the seeds of Lithospermum officinale were used internally as diuretic, anti-gout, antitoxic, antiovulatory, febrifuge, as anti-inflammatory in the urinary tract and for the stimulation of the digestion. The seedswere externally used for the elimination of foreign objects from the eyes. Lithospermum officinale roots were also used for the colouring of fibers and to obtain colors for makeup [80]. The herbal tea made from the root and stem was used for the treatment of smallpox, measles and as antipruritic [81].

\subsection{Lolium temulentum}

The seeds of Lolium temulentum are very nutritious and used for making bread. However, it is not advisable to eat it because sometimes it can be infected with an endophytic fungus Endoconidium temulentum, which is the source of the toxic pyrrolizidine alkaloids. This fungal infection, causes hallucinations in small doses and can, in larger quantities, cause severe damage to the nervous system. Slovenian ethnical groups living in western Hungary reportedly mixed the seeds of Lolium temulentum with those of barley to enhance the narcotic effects of beer. This grass was used medicinally by the ancient Greeks and Romans. Darnel was employed in headache, rheumatic meningitis, and in sciatica [82-85].

\subsection{Luffa acutangula}

Immature fruits of less-bitter cultivars of Luffa acutangula were used as a vegetable. They were cooked or fried and used in soups and sauces. Occasionally, the stem tops with young leaves and flower buds were used as a leafy vegetable. In South-East Asia, ridged gourd was a popular vegetable because of the mildly bitter flavor, the slightly spongy texture and sweet juiciness. Young fruits of sweet cultivars were also eaten raw and small fruits were sometimes pickled. The seeds yield an edible oil that is, however, sometimes bitter and toxic. The best sponges come from maturegreen fruits, although dry fruits may be used. The fruits were soaked for several days and then peeled. Once cleaned, the sponges were bleached and then dried in the sun, and were used for cleaning, filtering, and bathing. It was used traditionally in insect bites by tribes of Western Maharashtra [86-88]. Decoction of leaves was used for amenorrhea. Poultice of leaves was used for hemorrhoids. Juice of fresh leaves was used for granular conjunctivitis in children, to prevent the lids from adhering at night from excessive secretion and used externally for sores and various animal bites. Pulp of fruit was used internally, like calocynth, to cause vomiting and purging. Powdered dried fruit made into snuff for use by those afflicted with jaundice. Seed oil was used in dermatitis. In Russia, roots was used as a purge, In Iran and Iraq infused seeds was used as purgative and emetic, In India, roots was used in dropsy and as laxative and leaf and fruit juice were used in jaundice, In Bangladesh, pounded leaves was used in hemorrhoids, splenitis, leprosy, and the juice of leaves was used for conjunctivitis in children, In West Africa, leaf extract of ridged gourd was applied to sores caused by Guinea worms, leaf sap was used as eyewash in conjunctivitis and the fruits and seeds were used in herbal preparations for treatment of venereal diseases. InMauritius, seeds were eaten to expel intestinal worms, while leaf juice was applied externally in eczema [89].

\subsection{Luffa cylindrica}

Luffa cylindrica was used in wide application in packing medium, shoes mats, sound proof linings, bath sponges, utensil cleaning sponges, adsorbent for removal of heavy metal (such as nickel, lead, chromium, copper, etc) in waste water, and immobilization matrix for plant, algae, bacteria and yeast [90]. It was used traditionally for the treatment of asthma, intestinal worms, sinusitis, chronic bronchitis pain, carbuncles, abscesses, inflammation, heat rashes of children in summer, bowels or bladder hemorrhage, hemorrhoids, jaundice, menorrhagia, haematuria, leprosy, spleenopathy, as anthelmintic, carminative, emmenagogue, galactagogue and as antiseptic [91-94]. The fruit pulp of Luffa cylindrica was used to induce hemostasis, resolve phlegm and clear fever in traditional Korean medicine [95].

\subsection{Lycium barbarum}

The fruits were used for the production of juice, wine and tincture. In the traditional medicine, it was used to enhance immune system function, help eyesight, protect the liver, boost sperm production, and improve circulation [96-100]. It was used in traditional Chinese Medicine as mild tonic, to enrich liver, kidneys and moistening lung. It was indicated in dizziness, blurry vision, diminished visual acuity, nocturnal emission, night sweating, infertility, impotency, soreness and weakness of the lower back and knees, headache, prevention of premature aging, prematurely grey hair, abdominal pain, fatigue, to replenish vital essence, wasting and thirsting disorder (diabetes), blood deficiency (anemia), dry cough, cough with blood or blood streaks and to increase longevity [101-104]. 


\subsection{Lycopus europaeus}

Traditionally, this herb was used to cure coughs, respiratory disorders and as a natural remedy for sleeplessness. It was also used as a natural treatment for hyperthyroidism and for some symptoms of Grave's disease, such as palpitations. Furthermore, it was used as astringent and cosmetic in turkey, for the treatment of fever in Iraq and Turkey, as refrigerant, for the treatment of wounds and hyperthyroidism in India. It was also used in vascular excitement; hemorrhage, in small amounts, resulting from determination of blood to the lungs, kidneys, or gastro-intestinal organs; albuminuria, with frequent pulse; cough, with copious expectoration of mucus or muco-pus, especially debilitating chronic cough; wakefullness and morbid vigilance, with inordinately active circulation; frequent pulse, with high temperature, and in tubercular deposits [105].

\subsection{Lythrum salicaria}

Lythrum salicaria was known as medicinal plant from the ancient Greek and Roman times. The aerial parts of Lythrum salicaria were used internally for the treatment of diarrhea, chronic intestinal catarrh, hemorrhoid, eczema, as a decoction or fluid extract. Externally, it was used in the treatment of varicose veins, bleeding of the gums, hemorrhoid, eczema and vaginitis. It was also used as a demulcent and astringent decoction for the treatment of colorectitis, summer complaints of children diarrhoea; locally for chronic ophthalmic and as a wash or poultice for leucorrhoea, gleet (gonorrheal discharge), and chronic gonorrhea [106-110].

\subsection{Malva neglecta}

Due to its high mucilage content, it was used as soothing demulcent herbs, especially for cases of inflammation, either for the urinary, digestive or respiratory systems. Pregnant women or new mothers used mallow leaves as a source of iron, zinc and vitamins. Malva neglecta was substituted for spinach in many dishes, including soups, salads, gnocchi and quiche. Leaves and flowers were used for the treatment of constipation, sore throat,omen sterility, wound, hemorrhoids, miscarriage swellings, rheumatic pain, stomachache, abdominal pain, abscess, renal diseases, cough, throat infection, common cold, bronchitis,

peptic ulcer and indigestion. Stems and roots were used as abortifacient [111-113]. Malva neglecta was used in the treatment of common cold and to relieve cough in different parts of Iran. It was also used as a valuable and useful medicine to relieve the bruise, inflammation and mosquito bite. It was consumed for the treatment of urinary tract or digestive system diseases as well [114]. The pulverized mallow seeds are used to treat bladder ulcers and coughs [115]. In Italy the plant was used as tea in inflammation and as a gargle in sore throat. It also was also used to treat acne, broken bones, help in abdominal pain and to treat swelling, dermatitis, burns and throat infection [116-117].

Malva neglecta fruit was an edible traditional medicinal plant used in Anatolia to cure multiple medical conditions such as asthma, stomachache and diarrhea. It also used to promote maturation of abscesses, in wound healing, abdominal pains and cancer [118-119].

\subsection{Mangifera indica}

Most parts of the tree were used medicinally for abscesses, tumour, snake bite, datura poisoning, wounds, diarrhoea, indigestion, liver disorders, excessive urination, anemia, tetanus, bronchitis and asthma. Aqueous extract of mango bark was used in Cuba by patients suffering from elevated stress [120]. The immature fruit, when sliced and dried, was used in septicemia. The leaves were steeped to produce a tea with a cooling effects, the liquid was used as a bath to treat fever and cold. The bark was considered diuretic, astringent hemostatic and antirheumatic when used in hot local baths and hot dressings. It was used in a wash for blennorrhea. The seeds were used to treat clods, coughs, diarrhea, bleeding piles. The raw kernels were considered to be anthelmintic and used in the treatment of diarrhea. The resin was a remedy for aphthae, syphilis, and dysentery. The resin was used in cutaneous disease, the juice of kernel was snuffed to stop nasal bleeding, a decoction of the leaves with a little honey was given in aphonia, the loss of voice. Mid ribs of the leaves calcined and used to remove warts on eyelids. Tender leaves, were dried and made into a powder, and used in diabetes. Smoke of the leaves was said to have a curative effect in some infections of throat diseases. Ashes of leaves were a popular remedy for burns and scalds. Dried flowers in decoction powder was used in diarrhea, chronic dysentery and gleets. Powder of flowers were used as fumigation against mosquitoes. Gum resin of the tree was applied in cracked feet. A fluid extract form bark or rind was used for haemorrhage from the lungs, the uterus or intestine [121].

The leaf decoction was used as stomachic, anti-diarrheic, for genito-urinary inflammations, bronchitis, asthmas and in external use, in baths or washes against scabies and syphilis [122]. In the Northern region of Nigeria, the decoction of the stem bark extract was traditionally used for the treatment of wound and anemia [123-124]. 


\subsection{Marrubium vulgare}

Marrubium vulgare was used for dyspeptic complains and for loss of appetite. It also used as a choleretic or cholagogue herb [125]. Many Native American tribes extensively used the plant in formulations containing the leaves, or the leaves and flowers, for treatment of cough, mixed with honey because it is extremely bitter. Native Americans also used the root topically for rheumatoid arthritis [126]. In Mexico, the decoction of Marrubium vulgare was used in the traditional medicine for treatment of diabetes [127]. The herb was applied for the treatment of joint pain, inflammation, sore eyes, cough, bronchitis, pulmonary infections, cold and night blindness. The plant was also used to help in expulsion of fetus, as purgative, diuretic, bitter tonic, carminative and appetizer [128-129]. Marrubium vulgare raw material was recommended as a drink to accelerating the digestion processes [130-131].

\subsection{Matricaria chamomilla}

The essential oils of flower heads of Chamomilla recutita characterized by flavoring and coloring properties and for these properties, it was widely used in industry for commercial products like soaps, detergents, perfumes, lotions, ointments, hair products, baked goods, confectioneries, beverages and herbal teas [132].

Matricaria recutita was one of the most popular herbal medicine. The flowers were used for centuries for their antiinflammatory, analgesic, antimicrobial, antispasmic and sedative properties. The infusion of chamomile was used traditionally to calm nerves and reduce anxiety, and to treat hysteria, nightmares, insomnia and other sleep problems. The infusion was also used for relieving gastrointestinal disorders, especially in babies and small children and for the treatment of flu and bronchitis [133-134].

In external use, the camomile was applied in badly healed wounds, a bath for the abscesses, the female furoncles, hemorrhoids and genital diseases and for babies to soften the skin. It was also used in acne [135].

\subsection{Medicago sativa}

Medicago sativa sprouts were consumed as vegetable salad. Its leaves or seeds were also sold as bulk powdered herb, capsules, and tablets for nutritional supplement in health food stores [136]. It was used traditionally as Ayurvedic and homoeopathic medicine in central nervous system disorders, kidney pain, diabetes, inflammation and obesity [137138]. Alfalfa sprouts or leaves were also used traditionally for the treatment of arthritis, kidney problems, fever, as anticancer, anti-rheumatic, cardiotonic, depurative, lactagogue, emmenagogue, antiscorbutic and in the treatment of boils. In South America the plant was used as diuretic and in the treatment of kidney and vesicular swelling [139-140].

\subsection{Melia azedarach}

It was used traditionally in the treatment of intestinal worms, skin diseases, stomach ache, nausea, vomiting, paroxysmal fever, sciatica, lumbago, piles, asthma, wounds, diabetes, post labor pain, ammenorrhoea and leucoderma [141-142]. It was said that the plant was beneficial in the treatment of leprosy, inflammation, scrofula, anthelmintic, antilithic, diuretic, deobstruent and cardiac disorders [143].

Leaf extract was given orally twice a day for pyrexia [144], to relieve headache, locally applied in the treatment of burn and other skin diseases, as laxative, and prepared as mouth wash for gingivitis. Leaves and seed were used as insecticide. Stem bark infusion was used in gonorrhea [145]. The seed oil of was used in traditional medicine as antidiabetic, antifertility, antibacterial, and for wound healing [146].

\subsection{Melilotus Officinalis}

The plant was used as aromatic, emollient, demulcent, maturant, tonic, aphrodisiac, carminative to relieve flatulence and externally applied as poultice for pains and aches. The small fruits were used as demulcent, maturant, tonic, aphrodisiac and in leucoderma [147]. Herbal tea was used as a wash and rinse for swelling and swollen glands, abscesses, and swelling of the lymph nodes. Tea herbs, or the flowers themselves, were applied in cases of cold, mucosity, and respiratory and gastrointestinal disorders. It was also used in idiopathic headaches, long-standing neuralgias, coldness, tenderness, lameness or marked soreness of joints, cold, menstrual colic, ovarian neuralgia, colic with diarrhoea and much [148-149].

\subsection{Melissa officinalis}

The plant was used in folk medicine to enhance memory, as cardiotonic, as antidepressant and anxiolytic, and in the treatment of cardiovascular, respiratory and mental disorders [150]. It was recommended as juice, cream, or tea infusion for nervous complaints, lower abdominal disorders, gastric complaints, hysteria and melancholia, chronic 
bronchial catarrh, migraine, nervous debility, toothache, earache, headache, hypertension, and externally, for rheumatism, nerve pains, and stiff necks [151]. It was used in Europe as carminative, digestive, diaphoretic, stimulant, calmative, antiseptic and for the treatment of headache, migraine, insomnia, anxiety, nausea vertigo, syncope, anemia, asthma, bronchitis, amenorrhea, heart failure, arrhythmias, epilepsy and rheumatisms. The plant was also used for cosmetic purposes [152-154].

\subsection{Mentha longifolia}

The leaves were consumed as herbal tea and used as spice. The leaves, flowers and stems were used as carminative, antispasmodic, antiemetic, stimulant, analgesic, anti-asthmatic, in stomach ache and to enhance digestion [155-157]. The aerial parts were commonly used for the treatment of cold, cough, asthma, and chest inflammations, including pulmonary tuberculosis. Externally, Mentha longifolia was used to treat wounds and swollen glands [158]. In Iraq, the leaves were used for sore throat, minor mouth, throat irritation, aches, sprains, and as nasal decongestants [159]. In Egypt, the plant was used as analgesic, anti-pyretic, sedative, digestive, for wound healing and as anti-inflammatory [160-161].

\subsection{Mirabilis jalapa}

Leaves were employed for poulticing abscesses and boils. Juices of the leaves were used in treatment of skin allergy, and in earaches in children. Leaves infusion was applied topically to reduce swelling in conditions like bone fractures or twisting. Decoction of Mirabilis Jalapa was used orally as diuretic and in the treatment of kidney infections. Stems were used as tonic. The root of Mirabilis Jalapa was used traditionally as cathartic, purgative, emetic, in the treatment of abnormal accumulation of pus and or liquid and for inflamed and enlarged lymph-nodes [162-164].

\subsection{Momordica charantia}

The fruit was considered as tonic, stomachic, stimulant, emetic, antibilous and laxative. It was used in the treatment of gout, rheumatism and subacute cases of the spleen and liver diseases. The fruit juice and/or a leaf tea was employed for diabetes, malaria, colic, wounds, infections, worms and parasites, as an emmenogogue, and for measles, hepatitis, and fevers. Root was considered as astringent, abortifacient, anthelmintic [165].

In India, the fruits, seeds and leaves of the plant were used traditionally in the treatment of diabetes [166]. In China, it was used as an appetite stimulant, and in the treatment of gastrointestinal infection [165]. The plant was used in various Asian traditional medicine to stimulate digestion and in dyspepsia and constipation. In Brazil, the plant was used in the treatment of tumors, wounds, rheumatism, malaria, leucorrhea, inflammation, menstrual problems, diabetes, colic, fevers, worms, to induce abortions and topically for skin problems, vaginitis, hemorrhoids, scabies, itchy rashes, eczema, and leprosy. In Mexico, the plant was used in the treatment of diabetes and dysentery. In Peruvian herbal medicine, the leaf or aerial parts of the plant were used to treat measles, malaria, and all types of inflammation. In Nicaragua the leaf was commonly used for stomach pain, diabetes, fevers, colds, coughs, headaches, malaria, skin complaints, menstrual disorders, aches and pains, hypertension and infections [167].

\subsection{Morus alba}

The fruits were used as analgesic, anthelmintic, antibacterial, antirheumatic, diuretic, hypotensive, hypoglycemic, purgative, restorative, sedative and tonic. Fruits were also used as liver and kidney tonic and blood producing stimulator. Roots were used as cooling, sedating, diuretic, tonic, astringent and in the treatment of nervous disorders. Twigs were used as antirheumatic and nervine. Leaves were used as diaphoretic, refrigerant and antipyretic [168-169]. In traditional Chinese medicine, the fruits were used in the treatment of fever, eye diseases, as sudorific, anti-parasitic, hypolipidemic, hypotensive, for rinsing throat in inflammations of upper respiratory system. While, root extracts were used as anti-inflammatory, painkillers and for protection of liver and kidneys [170].

\subsection{Morus nigra}

Morus nigra was used in folk medicine as an analgesic, diuretic, antitussive, sedative, anxiolytic, hypotensive, and in the treatment of inflammatory disorders [171].

\subsection{Musa paradisiacal}

The fruit was used for its nutritional values all over the world [172]. Different parts of this plant (fruit, pulp, leaves) were used in folk medicine for the treatment of peptic ulcer, pain, asthma, burns, diabetes, dysentery, headache, inflammation, rheumatism and tuberculosis [173]. The leaf juice was use to treated insects bites. Leaves were used as an arbortifacient. Sap of the plants was used in the treatment of diarrhea, dysentery, hysteria and epilepsy. The root 
was used to treat general weakness, anemia, as antiscorbutic, aphrodisiac, and diuretic. Stem extracts were used in the treatment of hyperoxaluric urolithiasis, high blood pressure and kidney disease [174-175].

\subsection{Myrtus communis}

Myrtle was used for medicinal, food and spice purposes since ancient times. The decoction of myrtle aerial part was used as hypotensive, hypoglycemic, anti-inflammatory, for treatment of urethritis, diarrhea, peptic ulcers, hemorrhoids, bleeding, headache, palpitation, leucorrhoea, epistaxis, conjunctivitis, excessive perspiration, pulmonary and skin diseases [176-178]. Fruits were used as antiseptic, astringent, carminative, demulcent, analgesic, anti-inflammatory, antiemetic, diuretic, haemostatic, nephroprotective, for stomachic, and as antidiabetic. Leaves were used as flavouring agent, astringent, antiseptic, blood purification, hypoglycaemic, laxative, analgesic, haemostatic, stimulant and in the treatment of constipation and respiratory diseases [179-180].

\subsection{Narcissus tazetta}

Narcissus tazetta was used in the treatment of Alopecia areate, for the prevention and treatment of damaged skin resulting from conditions like acne vulgaris, atopic dermatitis, alopecia, vitiligo, pruritus, eczema, etc. An essential oil obtained from the flowers was used in perfumery [181]. It was said that the plant possessed emetic, cathartic, antispasmodic, and narcotic properties. It was used in epilepsy, in hysteria, and other spasmodic affections. The root was used to relieve headaches. The chopped root was applied externally as an antiphlogistic and analgesic poultice in abscesses, boils and other skin complaints. In Jordan, the infusion of the aerial parts and flowers were used as anticancer, anti-inflammatory, memorigenic, and sedative. The Bulbs of Narcissus tazetta was used for the treatment of breast cancer [182-184].

\subsection{Nasturtium officinale}

It was eaten as a vegetable or salads. The leaves were widely used as a depurative, diuretic, expectorant, hypoglycaemic, hypolipidemic, odontalgic, stimulant, for the treatment of pulmonary diseases, hypertension and cardiovascular diseases. It was also used in abdominal pain, as anti-ulcerogenic, in the treatment of scurvy, tuberculosis, bronchitis, influenza and asthma [185-189].

\subsection{Nerium oleander}

The leaves were used externally in chronic and obstinate skin diseases including leprosy and alopecia. The powder of leaves was used as a snuff for treating epilepsy. Root powdered with water was applied to alleviate venereal diseases and for the treatment of haemorrhoids [190].

\subsection{Nicotiana tabacum}

The written history of tobacco started in the year 1492 when Christopher Columbus discovered American Indians treating patients with leaves of (Nicotiana tabacum) an herb which he had never seen before. In 1536, European travelers to the New World carried home a considerable medical knowledge concerning the plant, acquired from Native American. Then the Western European physicians adopted tobacco as medicine [191-192]. Tobacco plant was used mainly as an ingredient of cigarettes, cigars and chew. Tobacco has long been removed from pharmacopoeias and from medical practice. However, tobacco traditionally used for wide range of disorders, it administered externally for bites of poisonous reptiles and insects, pain, neuralgia, gout, to enhance hair growth, in the treatment of ringworm, ulcers, wounds and as respiratory stimulant. It was administered by rectum in constipation and haemorrhoidal bleeding, administered orally in strangulated hernia, malaria or intermittent fever, dislodging obstructive material from oesophagus by inducing vomiting, and it administered by inhalation in nasal polyps. An ointment made of burned tobacco leaves mixed with lanolin was used as dessicant, stimulant and antiseptic for pruritus, ringworm, athlete's foot, superficial ulcers and wounds [193-195].

\subsection{Nigella sativa}

The seeds were used as appetizer, stimulant, diuretic, emmenagogue, galactagogue, anthelmintic, thermogenic, carminative, anodyne, deodorant, digestant, constipating, sudorific, febrifuge, expectorant, purgative, abortifacient, for the treatment of ascites, cough, jaundice, hydrophobia, fever, paralysis, conjunctivitis, piles, skin diseases, dyspepsia, flatulence, abdominal disorders, diarrohoea, dysentery, intrinsic hemorrhage and amenorrhea [196-200].

\subsection{Ocimum basilicum}


The essential oil of Ocimum basilicum were used in food industry as aromatic and flavoring ingredients. Ocimum oils were used in perfumery industry for a long time. It was also used traditionally for the treatment of cancer, convulsion, diarrhea, epilepsy, gout, nausea, sore throat, toothaches, bronchitis, rhinitis, mental fatigue, cold, spasm and as a first aid treatment for snakebites and wasp stings [201-204].

\subsection{Olea europaea}

The edible oil extracted from the mesocarp (pulp) of the fruit was the main product of the olive tree, it was commonly used as a cooking and salad oil. It was much appreciated for its flavor and beneficial effects on health. Lower grade olive oil was used in the manufacture of soap, cosmetics and lubricants. Leaf was applied on fresh wounds as a styptic, and used in the treatment of malaria, diabetes, coughs, urinary tract infections, backaches, kidney problems and to stop nose bleeds as a snuff. Leaf infusion was used as lotion for the treatment of eye infections and relieve sore throats and diphtheria [205-208].

\subsection{Ononis spinosa}

The roots, leaves and flowers were used as antitussive, aperient, diuretic and lithontripic. The plant infusion was used in the treatment of dropsy, urinary tract infections, inflammations and rheumatism [209]. Externally, it was used for the healing of wounds, eczema and the other skin disorders [210]. In Iraq, the aerial part decoction was used as diuretic and mild laxative, and the roots were used as diuretic, blood purative and expectorant [211].

\subsection{Onopordum acanthium}

Seed oil was used for burning and cooking [212]. Onopordum acanthium was used in Europe as an edible plant [213]. In Bulgarian folk medicine, the plant was used as refreshing and invigorating [214]. Onopordum acanthium was also used as bactericide, cardiotonic and hemostatic and for the treatment of hypotonicity; ripe seeds were used for heart diseases, poor blood circulation, as bactericidal, as hemostatic, diuretic, to treat nervousness and as antitumor agents. Aqueous extract of Onopordum acanthium, was used in Jordan traditional medicine in the treatment of various type of cancer. The plant was also used to diminish discharges of mucous membranes, and topically for skin cancer. The infusion of leaves and inflorescences was used to decreases edema of various origins [215-217].

Inflorescences, roots, seeds, and late developing leaves of Onopordum acanthium were used internally in the traditional medicine of Central Asia for the treatment of inflammation of the bladder and the respiratory and urinary systems [217218].

\subsection{Orchis mascula}

Various kinds of Orchis under the name of Sahlep were used for making a wholesome and nutritious drink of the same name. It was rich in mucilage, which formed a soothing and demulcent jelly that was used in the treatment of irritations of the gastro-intestinal canal. One part of Salep to fifty parts of water was sufficient to make a jelly. It was used traditionally as astringent, demulcent, expectorant, nutritive, restorative, invigorator and sexual tonic. In addition to its aphrodisiac effect, it was also used in the treatment of male sexual disorders like erectile dysfunction and impotence, and also as a nervine tonic to treat stress and mental disorders. Furthermore, the plant was also used for the treatment of hypertension and dyslipidemia and given in all forms of wasting diseases [219].

\subsection{Origanum vulgare}

Oregano was an important flavouring herb in Mediterranean cookery, and was often used dried rather than fresh. The leaves were used as a flavouring for salad dressings, vegetables and legumes, and were frequently included in strongly flavoured dishes with chillies, garlic, onions, etc. Flowering branches were used as energy producer, stomach booster, nervous calming, laxative, diarrhea, general weakness of the body, anticancer, migraine, for external use by rubbing in place of numbness and in toothache [220]. Aerial parts were used as disinfection, pain reliever, relaxing, cardiorespiratory booster, antidiarrheal, stomach booster, cough suppressant, sexual dysfunction, sinusitis [221-223]. Seed were bused as anticonvulsant, expectorant, pain reliever, cough suppressant, antidiarrheal, anti-inflammatory, menstrual regulator, diuretic and for the treatment of urinary tract infection [224].

\subsection{Oxalis corniculata}

Juice was taken by to enhance appetite and stop stomach upset including diarrhea and vomiting in adults, children and infants, it also used as anti-nausea in pregnant mothers, and for the treatment of tonsillitis, cough and to enhance wound healing [225]. It was used in the treatment of anemia, dyspepsia, indigestion, dementia, convulsion, piles and jaundice. The leaves' paste was used for the treatment of headache. It also used in scorpion sting and to stop wound bleeding. A 
decoction of the roots was used to treat giddiness, dysentery, diarrhea and intestinal parasites. The leaves were used for cold, fever, cough, stomachache, to stop bleeding from wounds and as anthelmintic. It also was used in the treatment of colic, burning sensation of the chest, and menstrual disorders [226-230].

\section{Conclusion}

This study highlighted the importance of Iraqi medicinal plants in the treatment and management of human diseases and ailments as known by traditional medicine.

\section{Compliance with ethical standards}

\section{Acknowledgments}

I acknowledged the dean of Thi qar college of medicine for scientific support.

\section{Disclosure of conflict of interest}

The authors confirm that this paper's content has no conflict of interests.

\section{References}

[1] Al-Snafi AE, Talab TA, Majid WJ. Medicinal plants with central nervous activity - An overview (Part 1). IOSR Journal of pharmacy. 2019; 9(3): 52-102.

[2] Al-Snafi AE. Medicinal plants for prevention and treatment of cardiovascular diseases - A review. IOSR Journal ofPharmacy. 2017; 7(4):103-163.

[3] Al-Snafi AE. Medicinal plants possessed antioxidant and free radical scavenging effects (part 3)- A review. IOSR Journal ofPharmacy. 2017; 7(4): 48-62.

[4] Al-Snafi AE. Arabian medicinal plants affected female fertility- plant based review (part 1). IOSR Journal of Pharmacy. 2018; 8(7):46-62.

[5] Al-Snafi AE. Arabian medicinal plants affected male fertility- plant based review (part 1). IOSR Journal of Pharmacy. 2018; 8(7): 63-76.

[6] Al-Snafi AE. Arabian medicinal plants possessed gastroprotective effects- plant based review (part 1). IOSR Journal of Pharmacy. 2018; 8(7): 77-95.

[7] Al-Snafi AE. Arabian medicinal plants for the treatment of intestinal disorders- plant based review (part 1). IOSR Journal of Pharmacy. 2018; 8(6):53-66.

[8] Al-Snafi AE. Therapeutic properties of medicinal plants: a review of their respiratory effects (part 1). International Journal of Pharmacological Screening Methods. 2015; 5(2):64-71.

[9] Al-Snafi AE, Majid WJ, Talab TA. Medicinal plants with antidiabetic effects - An overview (part 1). IOSR Journal of pharmacy. 2019; 9(3): 9-46.

[10] Al-Snai AE. Iraqi medicinal plants with antibacterial effect- A review. IOSR Journal of Pharmacy. 2019; 9(8): 22103.

[11] Al-Snai AE. Iraqi medicinal plants with antifungal effect- A review. IOSR Journal of Pharmacy. 2019; 9(7): 16-56.

[12] Al-Snai AE. Iraqi medicinal plants with antiviral effect- A review. IOSR Journal of Pharmacy. 2019; 9(7): 57-75.

[13] Al-Snafi AE. Antiparasitic, antiprotozoal, molluscicidal and insecticidal activity of medicinal plants (part 2) - plant based review. SchAcad J Pharm. 2016; 5(6): 194-207.

[14] Al-Snafi AE. Anticancer effects of Arabian medicinal plants (part 1) - A review. IOSR Journal ofPharmacy. 2017; 7(4): 63-102.

[15] Al-SnafiAE.Arabian medicinal plants with dermatological effects- plant basedreview (part 1). IOSR Journal of Pharmacy. 2018; 8(10):44-73.

[16] Al-Snafi AE. Arabian medicinal plants with antiinflammatory effects- plant based review (part 1). Journal of Pharmacy. 2018; 8 (7): 55-100. 
[17] Al-Snafi AE. Arabian medicinal plants with analgesic and antipyretic effects- plant based review (Part 1). IOSR Journal of Pharmacy. 2018; 8(6):81-102.

[18] Al-Snafi AE. Immunological effects of medicinal plants: A review (part 2). ImmunEndoc\& MetabAgents in Med Chem. 2016; 16(2): 100-121.

[19] Al-Snafi AE, ThwainiMM. Nephro- protective effects ofArabian medicinal plants ( part 1).Research Journal of Pharmaceutical, Biological and Chemical Sciences. 2018; 9(5): 1504-1511.

[20] Al-Snafi AE, ThwainiMM. Arabian medicinal plants with hepatoprotective activity (part 1). Research Journal of Pharmaceutical, Biological and Chemical Sciences. 2018; 9(5): 1469-1497.

[21] Al-SnafiAE. Traditional uses of Iraqi medicinal plants. IOSR Journal of Pharmacy. 2018; 8(8): 32-96.

[22] Ashnagar A, Ghanad AR, Motakefpour M. Isolation and identification of major chemical components found in the leaves of Lagerstroemia indica plant grown in the city of Tehran, Iran. Int J ChemTech Res. 2013; 5(1):478-481.

[23] Philippine Medicinal Plants, Lagerstroemia indica, http:// www. stuartxchange .org/Melendres

[24] Al-Snafi AE. A review on Lagerstroemia indica: A potential medicinal plant. IOSR Journal of Pharmacy. 2019; 9(6): 36-42.

[25] Al-Snafi AE. Medicinal value of Lagerstroemia speciosa: An updated review. International Journal of Current Pharmaceutical Research. 2019; 11(5):18-26.

[26] Asghari G, Akbari M, Asadi-Samani M. Phytochemical analysis of some plants from Lamiaceae family frequently used in folk medicine in Aligudarz region of Lorestan province. Marmara Pharmaceutical Journal. 2017; 21(3): 506-514.

[27] Samadi S, Khaiyamiand M, Tappe AHG. A Comparison of important physical and chemical characteristics of six Lallemantia iberica (Bieb.) Fisch. and Mey. varieties. Pakistan Journal of Nutrition. 2007; 6(4): 387-390.

[28] Amanzadeh Y, KhosraviDehaghi N, Gohari AR, Monsef- Esfehani HR, Amanzadeh Ebrahimi ES. Antioxidant activity of essential oil of Lallemantia iberica in flowering stage and post-flowering stage. Research Journal of Biological Sciences. 2011; 6(3): 114-117.

[29] Shafiee S, ModaresMotlagh A, Minaee S, Haidarbigi K. Moisture dependent physical properties of dragons head seeds (Lallemantia iberica). Agricultural Engineering International: The CIGR E- Journal. 2009; XI: Manuscript 1192.

[30] Abdoli S, Shafagh-Kolvanagh J. Relationship between biological yield and some agronomic traits of common ecotypes of Lallemantia (Lallemantia iberica Fisch. et C.A. Mey) from Iran. J Bio \& Env Sci. 2017; 10(5): 267-274.

[31] Al-Snafi AE. Medical benefit of Lallemantia iberica- A review. To Chemistry Journal. 2019; 3: 128-133.

[32] Naghibi F, Mosaddegh M, Mohammadi S, Ghorbani A. Labiatae family in folk medicine in Iran: from ethnobotany to pharmacology. Irani J Pharm Res. 2005; 2: 63-79.

[33] Al-Snafi AE. Pharmacological and Therapeutic effects of Lallemantia royleana- A review. IOSR Journal of Pharmacy. 2019; 9(6):43-50.

[34] Mahmood S, Hayat MQ, Sadiq A, Ishtiaq S, Malik S, Ashraf M.Antibacterial activity of Lallemantia royleana (Benth.) indigenous to Pakistan. Afri J Microbiol Res 2013; 7(31): 4006-4009.

[35] Bozorgi M, Vazirian M. Antioxidant activity of Lallemantia royleana (Benth.) seed extract. Trad Intrgr Med. 2016; 1(4): 147-150.

[36] Ghannadi A, Zolfaghari B. Compositional analysis of the essential oil of Lallemantia royleana (Benth. In Wall.) Benth from Iran. Flavour Frag J. 2003; 18: 237- 239.

[37] Verma SC, Jain CL, Nigam S, Padhi MM. Rapid extraction, isolation, and quantification of oleanolic acid from Lantana camara L. roots using microwave and HPLC-PDA techniques. Acta Chromatographica. 2013; 25(1): 181199.

[38] Dharmagada VSS, Tandonb M, Vasudevan P. Biocidal activity of the essential oils of Lantana camara, Ocimum sanctum and Tagetes patula. Journal of Scientific \& Industrial Research. 2005; 64: 53-56.

[39] Barreto FS, Sousa EO, Campos AR, Costa JGM, Rodrigues FFG. Antibacterial activity of Lantana camara Linn and Lantana montevidensis Brig extracts from Cariri-Ceará, Brazil. Pharm. 2010;2(1): 42-44. 
[40] Al-Snafi AE. Chemical constituents and pharmacological activities ofLantana camara- A review. Asian J Pharm Clin Res. 2019; 129(12):10-20.

[41] Campbell CG, Grass pea. Lathyrus sativus L. Promoting the conservation and use of underutilized and neglected crops. 18. Institute of Plant Genetics and Crop Plant Research, Gatersleben/ International Plant Genetic Resources Institute, Rome, Italy. 1997; 92.

[42] Duke JA. Handbook of legumes of world economic importance, New York, Plenum Press. 1981; 199-265.

[43] Ahsan S, Jahan R, Ahmad I, Chowdhury H, Rahmatullah M. A survey of medicinal plants used by Kavirajes of Barisal town in Barisal district. Bangladesh American-Eurasian J Sust Agric. 2010; 4(2):237-246.

[44] Teklehaimanot R, Wuhib E, Kassina A, Kidane Y, Alemu T, Spencer PS. Patterns of Lathyrus sativus (grass pea) consumption and ODAP content of food samples in the lathyrism endemic regions of North West Ethiopia. Nutr Res 1993; 3:1113-1126.

[45] Al-Snafi AE. Chemical constituents and pharmacological effects of Lathyrus sativus- A review.IOSR Journal ofPharmacy. 2019; 9(6): 51-58.

[46] Afzal M, Al-Oriquat, Al-Hussan JM, Mohammed N. Flavone glycosides from Lawsonia inermis. Heterocycle. 1980; 14: 1973-1976.

[47] Al-Snafi AE. A review on Lawsonia inermis:A potential medicinal plant. International Journal of Current Pharmaceutical Research. 2019; 11(5):1-13.

[48] Markova A. The Herbalist. The golden recipes of traditional medicine, Éksmo-Forum, Moscow. 2007.

[49] Makhlayuk VP. Medicinal plants in Ffolk medicine. Niva Rossii, Moscow.1992.

[50] Herbal resources, duckweed - uses benefits and side effects, https://www. herbal-supplementresource.com/duckweed-usesbenefits-side-effects.html

[51] Al-Snai AE. Lemna minor:Traditional uses, chemical constituents and pharmacological effects- A review. IOSR Journal of Pharmacy. 2019; 9(8): 6-11.

[52] Sahranavard S, Naghibi F, Mosaddegh M, Esmaeili S, Sarkhail P, Taghvaei M, Ghafari S. Cytotoxic activities of selected medicinal plants from Iran and phytochemical evaluation of the most potent extract. Res Pharm Sci. 2009;4(2): 133-137.

[53] Uysal I, Onar S, KarabaCak, Çelik S. Ethnobotanical aspects of Kapıdağ Peninsula (Turkey). Biological Diversity and Conservation. 2010;3(3): 15-22.

[54] Al-Snafi AE. Constituents and pharmacological effects of Leontice leontopetalum- A review. To Chemistry Journal. 2019; 3: 103-108.

[55] Mukhopadhyay D, Parihar SS, Chauhan JS, Preeti, Joshi SC. Effect of temperature and desiccation on seed viability of Lepidium sativum L. New York Science Journal. 2010; 3: 34-36.

[56] Datta PK, Diwakar BT, Viswanatha S, Murthy KN, Naidu KA. Safety evaluation studies on Garden cress (Lepidium sativum L.) seeds in Wistar rats. International Journal of Applied Research in Natural Products. 2011; 4(1): 3743.

[57] Al-Yahya M, Mossa J, Ageel A, Rafatullah S. Pharmacological and safety evaluation studies on Lepidium sativum L seeds. Phytomedicine. 1994; 1(2): 155-159.

[58] Ahsan SK, Tarig M, Ageel M, Alyanya MA, Shah AH. Studies on some herbaldrugs used in fracture healing. International J Crude-Drug Research. 1989; 27(4): 235-239.

[59] Sharma S, Agarwal N. Nourishing and healing prowess of garden cress (Lepidium sativum Linn). Indian Journal of Natural Products and Resources. 2011; 2(3):292-297.

[60] Baytop T. Türkiye'de Bitkiler ile Tedavi. Nobel Tip Istanbul. 1999; 480-485.

[61] Adam SIA, Salih SAM and Abdelgadir WS. In vitro antimicrobial assessment ofLepidium sativum L. seeds extracts. Asian Journal of Medical Sciences. 2011; 3(6): 261-266.

[62] Mathews S, Singhal RS, Kulkarni PR. Some Phsiochemical characteristics of Lepidium sativum seeds. Nahrung 1993;37(1): 69- 71. 
[63] Al-Snafi AE. Chemical constituents and pharmacological effects of Lepidium sativum- A review. International Journal of Current Pharmaceutical Research. 2019; 11(6):1-10.

[64] Cheriet T, Mancini I, Seghiri R, Benayache F, Benayache S. Chemical constituents and biological activities of the genus Linaria (Scrophulariaceae). Nat Prod Res. 2015; 29(17):1589-1613.

[65] San Feliciano A, Gordaliza M, Miguel del Corral JM, de la Puente ML. Neo-clerodane diterpenoids from roots of Linaria saxatilis var. glutinosa. Phytochemistry. 1993; 33:631-633.

[66] Romussi G, Fontana N, De Tommasi N. Flavonoids from Cymbalaria muralis Gaernt. Phytotherapy Research. 1996; 10:S84-S85.

[67] Darias V, Martín-Herrera D, Abdala S, de la Fuente. Plants used in urinary pathologies in the Canary Islands. Pharmaceutical Biology. 2001; 39(3): 170-180.

[68] Berglund DR. Flax: New uses and demands. In: Janick J and A Whipkey (eds.). Trends in New Crops and New Uses. ASHS Press, Alexandria, VA, USA. 2002: 358-360.

[69] Richharia RH. Linseed. The Indian central oilseeds committee. Hyderabad, India. 1962: 155.

[70] Abuelgasim AI, Ali MI, Hassan A. Antimicrobial activities of extracts for some of medicinal plants. International Journal of Advanced and Applied Sciences. 2015; 2(2): 1-5.

[71] Usmanghani K, Saeed A, Alam MT. Indusyunic medicine: Traditional medicine of herbal, animal and mineral origin in Pakistan. Department of Pharmacognosy, Faculty of Pharmacy, University of Karachi, Pakistan. 1997.

[72] Pharmacopoeia commission of the ministry of public health, China. A colored atlas of the Chinese materia medica specified in pharmacopoeia of the people's republic of China. Joint publishing (HK) Co, Ltd. 1995.

[73] Dodoala R, Divit B, Koganti K, Prasad VSRG. Effect of ethanolic extract of Phyla nodiflora (Linn) Greene against calculi producing diet induced urolithiasis. Indian Journal of natural products and resources. 2010; 1: 314-321.

[74] The Useful Plants of India, Third Edition, New Delhi, Publication and Information Directorate, Council of Scientific and Industrial Research. 1986; 450.

[75] Nadkarni KM. Indian Materia Medica, Vol 1, Bombay, India, Popular Prakashan. 1954; 746.

[76] Anonymous. Medicinal plants of India. Indian Council of Medical Research, Vol II. 1987.

[77] Al-Snafi AE. Anti-inflammatory and antibacterial activities of Lippia nodiflora and its effect on blood clotting time. J Thi Qar Sci.2013;4(1):25-30.

[78] Al-Snai AE.Pharmacological and therapeutic effects of Lippia nodiflora (Phylanodiflora). IOSR Journal ofPharmacy. 2019; 9(8):15-25.

[79] Winterhoff H. Lithospermum Species. In: De Smet PAGM, Keller K, Hänsel R and Chandler RF (eds). Adverse effects of herbal drugs, Vol 2. Springer, Berlin, Heidelberg. 1993.

[80] Solcan L, Danu M, Irimia I, Bodi G. Use and possible significance of two species of Boraginaceae family inprehistory - a review of Cucuteni culture finds. Analele Ştiinţifice ale Universităţii, Alexandru Ioan Cuza din Iasi. Sectiunea II A, Biologie Vegetala. 2014; 60(2): 63-75.

[81] Al-Snafi AE. Chemical constituents and pharmacological effects of Lithospermum officinale. IOSR Journal ofPharmacy. 2019; 9(8): 12-21.

[82] Terrell EE. A taxonomic revision of the genus Lolium. Technical Bulletin, United States Department of Agriculture No. 1392, 1968 1-65.

[83] Moerman DE. Native American Ethnobotany. Timber Press, Portland. 1998: 927.

[84] Dannhardt G, Steindl L. Alkaloids of Lolium temulentum: isolation, identification and pharmacological activity. Planta Med. 1985;(3):212-214.

[85] Pavol E, Mária H, Mariana E. Historical and current distribution of segetal weed Lolium temulentum in Sloakia. Hacquetia. 2010; 9(1): 151-159.

[86] Misar AV, Upadhye AS, Mujumdar AM. CNS depressant activity of ethanol extract of Luffa acutangula var. amara C. B. Clarke fruits in mice. Indian Journal of Pharmaceutical Science. 2004; 66 (4): 463-465.

[87] PROTA4U, Luffa acutangula (L.), Roxb. Luffa acutangula https://www. prota4u.org/ database/protav8. asp?g=pe\&p=Luffa+ acutangula $+(\mathrm{L})+$ Roxb. 
[88] Stephens JM. Gourd, Luffa- Luffa cylindrica (L.) Roem., Luffa aegyptica Mill., and Luffa acutangula (L.) Roxb. http://edis.ifas.ufl.edu/mv071

[89] Al-Snafi AE. A review on Luffa acutangula: A potential medicinal plant. IOSR Journal of Pharmacy 2019; 9(9):5667.

[90] Demir H, Top A, Balkose D, Ulku S. Dye adsorption behavior of Luffa cylindrica fibers. Journal of Hazardous Materials. 2008; 153: 389-394.

[91] Chakravarty HL. Cucurbits of India and their role in the development of vegetable crops. In: Bates DM, Robinson RW and Jeffrey C (eds). Biology and utilization of the cucurbitaceae. New York, Cornell University Press. 1990: 325-334.

[92] Al-Snafi AE. Constituents and pharmacology of Luffa cylindrica- A review. IOSR Journal of Pharmacy. 2019; 9(9):68-79.

[93] Perry LM. Medicinal plants of East and Southeast Asia: Attributed properties and uses. Cambridge, Massachusetts and London, England: The MIT Press. 1980; 116.

[94] Khan K.W, Ahmed SW, Ahmed S. Analgesic activity of leaves, flowers and fruit peel of Luffa cylindrica (1.) Roem. Pharmanest. 2013; 4(6): 1401-1408.

[95] Ha H, Lim HS, Lee MY, Shin IS, Jeon WY, Kim JH, Shin HK. Luffa cylindrica suppresses development of Dermatophagoides farinae-induced atopic dermatitis-like skin lesions in Nc/Nga mice. Pharm Biol. 2015; 53(4): 555-562.

[96] Amagase H, Farnsworth NR. A review of botanical characteristics, phytochemistry, clinical relevance in efficacy and safety of Lycium barbarum fruit (goji). Food Res Int. 2011; 44: 1702-1717.

[97] Sze SCW, Song JX, Wong RNS, Feng YB, Ng TB, Tong Y, Zhang KYB. Application of SCAR (sequence characterized amplified region) analysis to authenticate Lycium barbarum (wolfberry) and its adulterants. Biotechnology and Applied Biochemistry. 2008; 51(1): 15-21.

[98] Zhang KY, Leung HW, Yeung HW, Wong RN. Differentiation of Lycium barbarum from its related Lycium species using random amplified polymorphic DNA. Planta medica. 2001; 67(04): 379-381.

[99] Zhao C, Li R, He Y, Chui G. Studies on chemistry of gouqi polysaccharides. Yie Daxue Xuebao. 1997; 29: 231-232.

[100] Yin G, Dang Y. Optimization of extraction technology of the Lycium barbarum polysaccharides by Box-Behnken statistical design. Carbohydrate Polymers. 2008;74(3): 603-610.

[101] Potterat 0. Phytochemistry, pharmacology and safety in the perspective of traditional uses and recent popularity. Planta Med. 2010; 76: 7-19.

[102] Bensky D, Clavey S, Stöger E. Chinese herbal medicine. Materia Medica Eastland Press, Inc. 3rd Ed. Seattle. 2004.

[103] Chen JK, Chen TT. Chinese medical herbology and pharmacology. Art of Medicine Press Inc, City of Industry,CA. 2004.

[104] Zhu YP. Chinese materia medica- Chemistry, pharmacology and applications. Harwood Academic Publishers, Amsterdam. 1998.

[105] Al-Snai AE. A review on Lycopus europaeus:A potential medicinal plant.IOSR Journal of Pharmacy.2019; 9(7): 8088.

[106] Rauha JP, Remes S, Heinonen M, Hopia A, Kahkonen M, Kujala T, Pihlaja K, Vuorela H, Vuorela P. Antimicrobial effects of Finnish plant extracts containing flavonoids and other phenolic compounds. Int J Food Microbiol. 2000; 56: 3-12.

[107] Mantle D, Eddeb F, Pickering AT. Comparison of relative antioxidant activities of British medicinal plant species in vitro. J Ethnopharmacol. 2000; 72: 47-51.

[108] Gonzez JA, Garcia-Barriuso M, Amich F. Ethnobotanical study of medicinal plants traditionally used in the Arribes del Duero, western Spain. Journal of Ethnopharmacology. 2010;131: 343-355.

[109] Eisenberg S. Viewpoints on a common weed: Lythrum salicaria. Journal of the American Herbalists Guild. 2006; 6(2): 39-43.

[110] Al-Snafi AE. Chemical constituents and pharmacological effects ofLythrumsalicaria - A review.IOSR Journal of Pharmacy. 2019; 9(6): 51-59. 
[111] Akaydın G, Şimşek I, Arıtuluk ZC, Yeşilada E. An ethnobotanical survey in selected towns of the Mediterranean subregion (Turkey). Turk J Biol. 2013; 37: 230-47.

[112] Yeşil Y, Akalın E. Folk medicinal plants in Kurecik area (Akcadağ/ Malatya-Turkey). Turk J Phar Sci. 2009; 2: 6382.

[113] Sezik E, Yaşilada E, Tabata M, Honda G, Takaishi Y, Fujita T. Traditional medicine in Turkey VIII. Folk medicine in east Anatolia, Erzurum, Erzincan, Area, Kars, Iğdır provinces. Econ Bot. 1997; 51: 195-211.

[114] Jafari-Sales A, Jafari B, Sayyahi J, Zohoori-Bonab T. Evaluation of antibacterial activity of ethanolic extract of Malva neglecta and Althaea officinalis L. on antibiotic resistant strains of Staphylococcus aureus. J Biol Today's Word. 2015; 4(2): 58-62.

[115] Aziz MA, Adnan M, Khan AH, Rehman AU, Jan R, Khan J. Ethno-medicinal survey of important plants practiced by indigenous community at Ladha subdivision, South Waziristan agency, Pakistan. Journal of Ethnobiology and Ethnomedicine. 2016; 12(1): 53.

[116] Pieroni A, Giusti M. Alpine ethnobotany in Italy: Traditional knowledge of gastronomic and medicinal plants among the Occitans of the upper Varaita valley. Piedmont. Journal of Ethnobiology and Ethnomedicine. 2009; 5(1): 32.

[117] Tuker M, Datar A. antioxidant and enzyme inhibitory properties and phenolic composition of M. neglecta Wallr (Malvaceae) fruit: A traditional medicinal fruit from Eastern Anatolia. Industrial Crops and Products. 2013; 51:376-380.

[118] Dalar A, Türker M, Konczak I. Antioxidant capacity and phenolic constituents of Malva neglecta Wallr and Plantago lanceolata L from Eastern Anatolia Region of Turkey. J Herb Med. 2012; 2(2): 42-51.

[119] Al-Snafi AE.Medical benefit of Malva neglecta - A review.IOSR Journal of Pharmacy. 2019; 9(6): 60-67.

[120] Garrido G, González D, Delporte C, Backhouse N, Quintero G, Núñez-Sellés AJ, Morales MA. Analgesic and antiinflammatory effects of Mangifera indica L. extract (Vimang). Phytother Res. 2001; 15(1):18-21.

[121] Nikhal S, Mahajan SD. Evaluation of antibacterial and antioxidant activity of Mangifera indica (leaves). J Pharm Sci \& Res. 2010; 2(1): 45-47.

[122] Santos FRO, Nogueira SAC, Vieira SB, Linhares FL, Sales de BEH, Paula CS, Gadelha RMF, Maia deMS. Effect of essential oils from Mangifera indica L. cultivars on the antifungal susceptibility of Candida spp. strains isolated from dogs. Rev Bras Saúde Prod Anim. 2017; 18(2): 337-346.

[123] Malami I, Musa MS, Alhasan AM, Dallatu MK, Abdullahi K. Hepatoprotective activity of stem bark extract of Mangifera indica L. on carbon tetrachloride-induced hepatic injury in Wister albino rats. IJPSR. 2014; 5(4): 12401245.

[124] Al-Snafi AE, Ibraheemi ZAM, Talab TA. A review on components and pharmacology of Mangifera indica. International Journal of Pharmaceutical Research. 2021; 13(2): 3043- 3066.

[125] Capasso, Francesco, et al. Phytotherapy: A quick reference to herbal medicine. Berlin, Heidelberg: Springer Berlin Heidelberg. 2003.

[126] Moerman, Daniel E. Native American ethnobotany. Portland, Timber Press. 2010.

[127] Castillo-España P, Monroy-Ortiz C. Plantas Medicinales Utilizadas en el Estado de Morelos. 2nd ed. Cuernavaca: Universidad Autónoma del Estado de Morelos. 2000.

[128] Mittal V, Nanda A. The pharmacognostical evaluation of the Marrubium vulgare Linn collected from the Pulwama district of Jammu and Kashmir state in India. Journal of Chemical and Pharmaceutical Research. 2016; 8(10):715.

[129] Kirtikar KR, Basu BD. Indian medicinal plants. International Book Distributors, Dehradun, India. 1996: 20072009.

[130] Pietroni A, Quave C, Nebel S, Heinrich M. Ethnopharmacy of the ethnic Albanians (Arbëreshë) of northern Basilicata, Italy. Fitoterapia. 2002; 73(3): 217-241.

[131] Al-Snafi AE.Al-Saedy HA, Talab TA, Majid WJ, El-Saber Batiha G, Jafari-Sales Abolfazl.The bioactive ingredients and therapeutic effects of Marrubium vulgare - A review. International Journal of Biological and Pharmaceutical Sciences Archive. 2021; 1(2):9-21. 
[132] Fajemiroye JO, Ferreira NL, de Oliveira LP, Elusiyan CA, Pedrino GR, da Cunha LC, da Conceição EC. Matricaria recutita and its isolate-apigenin: Economic value, ethnopharmacology and chemicobiological profiles in retrospect. Journal of Pharmacognosy and Phytochemistry. 2016; 4(4): 17-31.

[133] Sak K, Nguyen TH, Ho VD, Do TT, Raal A. Cytotoxic effect of chamomile (Matricaria recutita) and marigold (Calendula officinalis) extracts on human melanoma SK-MEL-2 and epidermoid carcinoma KB cells. Cogent Medicine. 2017; 4:1333218.

[134] Presibella MM, Villas-Bôas LD, Belletti KMD, Santos CAD, Weffort-Santos AM. Comparison of chemical constituents of Chamomilla recutita (L.) Rauschert essential oil and its antichemotactic activity. Brazilian Archives of Biology and Technology. 2006; 49(5): 717-724.

[135] Bencheikh D. Polyphenols and antioxidant properties of extracts from Mentha pulegium L and Matricaria camomilla L. MSC thesis. University of Ferhat Abbes Setif. 2012.

[136] Karimi E, Oskoueian E, Oskoueian A, Omidvar V, Hendra R, Nazeran H. Insight into the functional and medicinal properties of Medicago sativa (Alfalfa) leaves extract. Journal of Medicinal Plants Research. 2013;7(7):290-297.

[137] Doss A, Parivuguna V, Vijayasanthi M, Surendran S. Antibacterial evaluation and phytochemical analysis of Medicago sativa L. against some microbial pathogens. Indian Journal of Science and Technology. 2011; 4(5): 550552.

[138] Rana MG, Katbamna RV, Padhya AA, Dudhrejiya AD, Jivani NP, Sheth NR. In vitro antioxidant and free radical scavenging studies of alcoholic extract of Medicago sativa L. Rom J Biol (Plant Biology). 2010; 55(1):15-22.

[139] Contero F, Abdo S, Vinueza D, Moreno J, Tuquinga M, Paca N. Estrogenic activity of ethanolic extracts from leaves of Ilex guayusa loes and Medicago sativa in Rattus norvegicus. Pharmacology Online. 2015; 2:95-99.

[140] Al-Snafi AE, Khadem HS, Al-Saedy HA, Alqahtani AM, El-Saber Batiha G. Jafari-Sales Abolfazl.A review on Medicago sativa: A potential medicinal plant. International Journal of Biological and Pharmaceutical Sciences Archive. $2021 ; 1(2): 22-33$.

[141] Sharma PC, Yelne MB, Dennis TJ. Data base on medicinal plants used in Ayurveda, Documentation and Publication Division, Central Council for Research in Ayurveda and Siddha, New Delhi. 2001; 389-406.

[142] Warrier PK, Nambiar, Ramankutty VPK. Indian Medicinal Plants, A Compendium of 500 Species, Hyderabad, Orient Longman Limited. 1995.

[143] Descalzo AM, Coto C. Inhibition of the pseudorabies virus (Scisherpesvinyl) by an antiviral agent isolated from the leaves of Melia azedarach. Rev Argent Microbiol. 1989; 21:133-140.

[144] Sultana S, Akhtar N, Asif HM. Phytochemical screening and antipyretic effects of hydro-methanol extract of Melia azedarach leaves in rabbits. Bangladesh J Pharmacol. 2013; 8: 214-217.

[145] Khan AV, Parveen G, Alam MM, Singh VK. Ethnomedicinal uses of Neem in rural areas of Uttar Pradesh, India. Ethnomed and Pharmacog. II Rec. Prog. In Med Plants. 2002; 7: 319-326.

[146] Roop JK, Dhaliwal PK, Guraya SS. Extracts of Azadirachta indica and Melia azedarach seeds inhibit folliculogenesis in albino rats. Braz J Med Biol Res. 2005; 38(6): 943-947.

[147] Kirtikar KR, Basu BD. Indian medicinal plants. 2nd ed. Vol I. Dehradun, International Book Distributors. 2005; 704-705.

[148] Bunney S. The Illustrated encyclopedia of herb. Their medicinal and culinary uses. Chancellor Press, London, UK. 1992: 190-198.

[149] Al-Snafi AE. Chemical constituents and pharmacological effects of Melilotus Officinalis- A review. IOSR Journal of Pharmacy. 2020; 10(1):26-36.

[150] Moradpour M, Ghoran SH, Asghari J. Phytochemical investigation of Melissa officinalis L. flowers from Northern part of Iran (Kelardasht). Journal of Medicinal Plants Studies. 2017; 5(3): 176-181.

[151] Cohen RA, Kucera LS, Herrmann E. Antiviral activity of Melissa officinalis (lemon balm) extract. Proceedings of the Society for Experimental Biology andMedicine. 1964; 117: 431-434.

[152] Gbolade AA, Lockwood G. The constituents of Melissa officinalis cell cultures. Planta Med. 1989; $55: 228$. 
[153] Carocho M, Barros L, Calhelha RC, Ciric A, Sokovic M, Santos-Buelga C, Morales P, Ferreira, ICFR. Melissa officinalis L. decoctions as functional beverages: A bioactive approach and chemical characterization. Food Funct. 2015; 6: 2240-2248.

[154] Mutalib LY.Physicochemical, phytochemical and biological study of Melissa officinalis growing naturally in Kurdistan region/ Iraq: Comparative study. IOSR Journal of Pharmacy and Biological Sciences. 2015; 10(5): 6772.

[155] Gulluce M, Shain F, Sokmen M, Ozezer H, Daferera D, Sokmen A. Antimicrobial and antioxidant properties of the essential oils and methanol extract from Mentha longifolia L. spp. longifolia. Food Chemical. 2007; 103: 14491456.

[156] Zargari A. Medicinal plants: Tehran University Press. 1990; 4: 28-42.

[157] Sahir Petkar S, Vuuren S. The chemo-geographica variation in essential oil compositon and the antimicrobial propertied of wild Mint Mentha longifolia subsp. polyadena (Lamiaceae) in southern Africa. J. Essent Oil Res. 2006; 18: 60-65.

[158] Bertoli A, Leonardi M, Krzyzanowska J, Oleszek W, Pistelli L. Mentha longifolia in vitro cultures as safe source of flavouring ingredients. Biochemica Bolonica. 2011; 58(4):581-587.

[159] Al-Bayati FA. Isolation and identification of antimicrobial compound from Mentha longifolia L. leaves grown wild in Iraq. Annals of Clinical Microb and Antimicrob. 2009; 12: 8-20.

[160] Eissa TAF, Palomino OM, Carretero ME, Gómez-Serranillo S. Ethnopharmacological study of medicinal plants used in the treatment of CNS disorders in Sinai Peninsula, Egypt. J Ethnopharmacol. 2014; 151(1): 317-332.

[161] Behboud Jafari, Salar Fatemi, Mehrdad Pashazadeh, Ali Esmail Al-Snafi, Afsoon Shariat. Antibacterial effects of Thymus vulgaris, Mentha pulegium, Crocus sativus and Salvia officinalis on pathogenic bacteria: A brief review study based on gram-positive and gram-negative bacteria. Jorjani Biomedicine Journal. 2020; 8(3): 58-66.

[162] Chetty KM, Sivagi K, Rao KT. Flowering plants of Chittoor district, Andra Pradesh, India. Student Offset Printers Trupati. 2008; 286.

[163] Watt JM, Breyer-brendwijk MG. The medicinal and poisnous plants of South Africa. E. and S. Livingstone, London. $1962 ; 801$.

[164] Al-Snafi AE,Talab TA, Jabbar WM, Alqahtani AM.Chemical constituents and pharmacological activities of Mirabilis jalapa-A review International Journal of Biological and Pharmaceutical Sciences Archive. 2021; 1(2):34-45.

[165] Sathish Kumar D, Vamshi Sharathnath K, Yogeswaran P, Harani A, Sudhakar K, Sudha P, Banji D.A medicinal potency of Momordica charantia. Intern J Pharmaceut Sci Rev and Res. 2010; 1(2): 95-100.

[166] Pullaiah T, Naidu KC. Antidiabetic plants in India and herbal based antidiabetic research. Regency Publications, New Delhi- India. 2003; 228-229.

[167] Anilakumar KR, Kumar GP, Ilaiyaraja N. Nutritional, pharmacological and medicinal properties of Momordica charantia. International Journal of Nutrition and Food Sciences. 2015; 4(1):75-83.

[168] Yamatake Y, Shibata M, Nagai M. Pharmacological studies on root bark of mulberry tree (Morus alba L.). Jpn J Pharmacol. 1976; 26: 461-469.

[169] Chen F, Nakashima N, Kimura M. Hypoglycemic activity and mechanism of extracts from mulberry leaves and cortex mori radices in streptozotocin induced diabetic mice. Yakugaku Zasshi. 1995; 115: 476-482.

[170] Katsube T, Imawaka N, Kawano Y, Yamazaki Y, Shiwaku K, Yamane Y. Antioxidant flavanol glycosides in mulberry (Morus alba L.) leaves isolated based on LDL antioxidant activity. Food Chemistry. 2006; 97(1): 25-31.

[171] Almeida JRGS, Souza GR, da Cruz Arajo EC, Silva FS, de Lima JT, Ribeiro LAA, Nunes XP, et al. Medicinal plants and natural compounds from the genus Morus (Moraceae) with hypoglycemic activity: A review. INTECH 2012.

[172] Jawla S, Kumar Y, Khan MSY. Antimicrobial and antihyperglycemic activities of Musa paradisiaca flowers. Asian Pacific Journal of Tropical Biomedicine. 2012; 2(2): S914-S918.

[173] Nadkarni KM. Indian Materia Medica. Vol I, 3rd Ed. Bombay Popular Prakashan. 1982; 822-827.

[174] Poonguzhali PK, Cheju H. The influence of banana stems extract on urinary risk factors for stones in normal and hyperoxaluric rats. British Journal of Urology. 1994; 74(1): 23-25. 
[175] Kibria AA, Kamrunnessa, Rahman M, Kar A. Extraction and evaluation of phytochemicals from banana peels (Musa sapientum) and banana plants (Musa paradisiaca). Malaysian Journal of Halal Research Journal. 2019; 2(1):22-26.

[176] Jabri MA, Tounsi H, Rtibi K, Marzouki L, Sakly M, Seba H. Ameliorative and antioxidant effects of myrtle berry seed (Myrtus communis) extract during reflux-induced esophagitis in rats. Pharmaceutical Biology. 2016; 54 (9): 1575-1585.

[177] Bouzabata A. Traditional treatment of high blood pressure and diabetes in Souk Ahras District. J Pharmacogn Phytother. 2013;5: 12-20.

[178] Boudjelal A, Henchiri C, Sari M, Sarri D, Hendel N, Benkhaled A, Ruberto G. Herbalists and wild medicinal plants in M'Sila (North Algeria): An ethnopharmacology survey. J Ethnopharmacol. 2013; 148: 395-4022.

[179] Sumbul S, Ahmad M A, Asif M, Saud I, Akhtar M. Evaluation of Myrtus communis Linn. berries (common myrtle) in experimental ulcer models in rats. Hum Exp Toxicol. 2010; 29(11):935-944.

[180] Aleksic V, Knezevic P. Antimicrobial and antioxidative activity of extracts and essential oils of Myrtus communis L. Microbiol Res. 2013;168(6): 311-332.

[181] Akram U, Azhar M, Pawan JA, Fazil KM, Ahmed S. Narcissus tazetta - a case study of biopiracy. Current Science 2012; 103(9): 978-979.

[182] Talib WH, Mahasneh AM. Antimicrobial, cytotoxicity and phytochemical screening of Jordanian plants used in traditional medicine. Molecules. 2010; 15: 1811-1824.

[183] Tomoda M, Yokoi M, Torigoe K, Maru K. Plant mucilages. XXVII. Isolation and characterization of a mucous polysaccharide, Narcissus-T-glucomannan, from the Bulbs of Narcissus tazetta var. chinensis. Chemical \& Pharmaceutical Bulletin. 1980; 28(11): 3251-3257.

[184] Al-Snafi AE.Constituents and pharmacology of Narcissus tazetta. IOSR Journal of Pharmacy. 2020; 10(9): 44-53.

[185] Zargari F, Ghorbanihaghjo A, Babaei H, Farajnia S, Roodbari NH. The effect of hydroalcoholic extract of Nasturtium officinale $\mathrm{R}$. Br on antioxidant status and DNA damage in liver and kidney rats exposed to arsenic. Med J Tabriz Univ Med Sci. 2014; 36(3): 44-49.

[186] Ozen T. Investigation of antioxidant properties of Nasturtium officinale (Watercress) leaf extracts. Acta Poloniae Pharmacutica Drug Research. 2009; 66(2): 187-193.

[187] Palaniswamy UR, Richard J, Bible MBB, Stuart JD. Ontogenic variations of ascrobic acid and phenathyl isothiocyanate concentration in watercress (Nasturtium officinale R. Br.) leaves. Journal of Agriculture and Food Chemistry. 2003; 51(18): 5504-5509.

[188] Chen L, Mohr SN, Yang CS. Decrease of plasma and urinary oxidative metabolites of acetaminophen after consumption of watercress by human volunteers. Clin Pharmacol Ther. 1996; 60(6): 651-660.

[189] Al-Snafi AE. A review on Nasturtium officinale: A potential medicinal plant. IOSR Journal of Pharmacy. 2020; 10(9): 33-43.

[190] Al-Snafi AE. Bioactive ingredients and pharmacological effects of Nerium oleander. IOSR Journal of Pharmacy. $2020 ; 10(9): 19-32$.

[191] Akehurst BC. Tobacco. Longmans, Green and Co., London. 1968; 2-11.

[192] Kishore K. Monograph of tobacco (Nicotiana tabacum). Indian Journal of Drugs. 2014; 2(1): 5-23.

[193] Charlton A. Medicinal uses of tobacco in history. J R Soc Med. 2004; 97(6): 292-6.

[194] Silvette H, Larson PS, Haag HB. Medical uses of tobacco: past and present. Virginia Med Monthly. 1958;85:472484.

[195] Batoro J, Ekowati G. An ethnobotanical tobacco (Nicotiana tabacum L.) in Indonesia. A review. Advances in Life Sciences. 2017; 7(2): 26-29.

[196] Warrier PK, Nambiar VPK, Ramankutty. Indian medicinal plants- A compendium of 500 species, Vol. 4. Orient Longman Pvt Ltd, Chennai. 2004; 139-142.

[197] Sharma PC, Yelne MB, Dennis TJ. Database on medicinal plants used in Ayurveda. Vol 6. CCRAS, New Delhi. 2005; $420-440$. 
[198] The Ayurvedic Pharmacopoeia of India. Part-1. Ministry of Health and Family Welfare, New Delhi. 1989; $119-120$.

[199] Al-Snafi AE, Adbul-Ghani M Al-Samarai, Mahmood Al-Sabawi. The effectiveness of Nigella sativa seed oil in treatment of chronic urticaria. Tikrit Journal of Pharmaceutical Sciences. 2005; 1(1): 1-6.

[200] Al-Snafi AE, Wajdy JM, Tayseer Ali Talab. Galactagogue action of Nigella sativa seeds. IOSRJournal of Pharmacy. 2014; 4(6): 58-61.

[201] Aburigal, YAA, Mirghani MES, Elmogtaba EY, Sirible AAM, Hamza NB, Hussein IH. Total phenolic content and antioxidantbcapacity of basil (Ocimum basilicum L.) leaves from different locations. International Food Research Journal. 2017; 24(Suppl):S378-S381.

[202] Antora RA, Salleh RM. Antihyperglycemic effect of Ocimum plants: A short review. Asian Pac J Trop Biomed. 2017; 7(8): 755-759.

[203] Chenni M, El Abed D, Rakotomanomana N, Fernandez X, Chemat F. Comparative study of essential oils extracted from Egyptian basil leaves (Ocimum basilicum L.) using hydro-distillation and solvent-free microwave extraction. Molecules. 2016; 21: 113.

[204] Al-Snafi AE. Chemical constituents and pharmacological effects of Ocimum basilicum- A review. International Journal of Pharmaceutical Research. 2021; 13(2): 2997-3013.

[205] Masoko P, Makgapeetja DM. Antibacterial, antifungal and antioxidant activity of Olea africana against pathogenic yeast and nosocomial pathogens. BMC Complementary and Alternative Medicine. 2015;15(409):1-9.

[206] Cuneo P, Leishman MR. African Olive (Olea europaea subsp. cuspidata) as an environmental weed in eastern Australia: A review. Cunninghamia. 2006; 9(4): 545-577.

[207] Long HS, Tilney PM, Wyk BEV. The ethnobotany and pharmacognosy of Olea europaea subsp. africana (Oleaceae). South African Journal of Botany. 2010;79:324-331.

[208] Agrawal M, Nandini D, Sharma V, Chauhan NS. Herbal remedies for treatment of hypertension. Intern J of Phamaceut Sci and Res. 2010;1(5):1-21.

[209] Altuner EM, Ceter T, Işlek C. Investigation of antifungal activity of Ononis spinosa L. ash used for the therapy of skin infections as folk remedies. Mikrobiyol Bul. 2010; 44(4): 633-639.

[210] Toglu GS, Altanlar N. Antimicrobial activity of some plants used in folk medicine. J Fac Pharm, Ankara. 2003; 32(3): 159-163.

[211] Al-Snafi AE.The traditional uses, constituents and pharmacological effects of Ononis spinosa. IOSR Journal of Pharmacy. 2020; 10(2):53-59.

[212] Grieve M. A modern herbal: The Medicinal Culinary Cosmetic and Economic Properties Cultivation and Folk-lore of Herbs, Grasses, Fungi, Shrubs \& Trees with All Their Modern Scientific Uses, V. 1, Dover Publication, New York. $1971 ; 888$.

[213] Lim TK. Edible medicinal and non-medicinal plants. Springer- Dordrecht, Netherlands. $2014 ; 7$.

[214] Petkov V. Modern phytotherapy. State Publishing House. Medicina I fizkultura. Sofia. 1982; 513.

[215] Bruno M, Maggio A, Rosselli S, Safder M, Bancheva S. The metabolites of the genus Onopordum (Asteraceae): Chemistry and biological properties. Current Organic Chemistry. 2011; 15: 888-927.

[216] Mobli M, Qaraaty M, Amin G, Haririan I, Hajimahmoodi M, Rahimi R. Scientific evaluation of medicinal plants used for the treatment of abnormal uterine bleeding by Avicenna. Arch Gynecol Obstet. 2015; 292: 21-35.

[217] Mamedov NA, Mehdiyeva NP, Crake LE. Medicinal plants used in traditional medicine of the Caucasus and North America. J Med Active Plants. 2015; 4: 42-66.

[218] Al-Snafi AE. Constituents and pharmacology of Onopordum acanthium. IOSR Journal of Pharmacy. 2020; 10(3):714.

[219] Al-Snafi AE. Pharmacological potential of Orchis mascula- A review. IOSR Journal of Pharmacy. 2020;10(3):1-6.

[220] Zolfeghari E, Adeli I, Mozafarian V, Babaiy S, Bibalan GHH. Identification of Arasbaran medicinal plants and ethnobotanical study of rural people knowledge (Case Study: Arasbaran forest, Mardanaghom watershed). Iran J Med Aroma Plants. 2012; 28(3): 534-50. 
[221] Khodayari H, Amani SH, Amiri H. Ethnobotanical study of Northeast of Khuzistan province. Med Plants Ecophytochemistry J. 2013;2(4):12-26.

[222] Dolatkhahi M, Ghorbani-Nahouji M, Mehr-Afarin A, Amininejad GHR, Dolatkhahi A. An ethnobotanical study of medicinal plants city Kazeroon: Identification, distribution and use of traditional. J Med Plants. 2012; 11(2): 16378.

[223] Sajadi SE, Batouli H, Ghanbari A. Collection and evaluation of the traditional selection of medicinal plants in Kashan. J Trad Med Islam Iran. 2011; 2(1):29- 36.

[224] Mehrabian AR, Abdoli A, Liaghati H, Mostafvi H, Ahmadzadeh F. Bushehr Province (N. E. Persian Gulf) as an important reservoir for plant biodiversity in Iran. Tropentag, Hohenheim. 2008.

[225] Tibuhwa DD. Oxalis corniculata L. in Tanzania: traditional use, cytotoxicity and antimicrobial activities. J Appl Biosci. 2016; 10055- 10063.

[226] Hebbar SS, Harsha VH, Shripati V, Hedge GR. Ethnomedicine of Dharwad district in Karnataka, India. Journal of Ethnopharmacology. 2004; 94:261-266.

[227] Madhavachetty K, Sivaj JK, Rao TK. Flowering plants of Chittor district, Andhra Pradesh, India. Student Offset Printers- Tirupati. 2008; 1:54-55.

[228] Sumei L, Chuein L, Fengyan L, Sangwoo L, Yuheng RL. Herbs for medicinal baths among the traditional Yao communities of China. Journal of Ethnopharmacology. 2006; 108:59-67.

[229] Mohammad IS, Mir AK. Folk use of medicinal herbs of Margalla Hills National Park, Islamabad. J Ethnopharmacol. 2000; 69: 48-56.

[230] Anonymous. Formulary of Siddha Medicines. The Indian medical practitioners Co. Operative Pharmacy and Stores Ltd. Adyar Madras. 1972; 25. 